\title{
Explaining and Understanding State Intervention into the Lives of 'Troubled' Families
}

\section{Sadie Parr}

Centre for Regional, Economic and Social Research (CRESR), Sheffield Hallam University

E-mail: S.Parr@shu.ac.uk

This article focuses attention on explaining and understanding state intervention into the lives of families deemed 'troublesome' with specific attention on the Troubled Families Programme. Launched in 2011, in part as a response to the London riots, the Troubled Families Programme represented an escalation and intensification of state intervention into the lives of families. Policy analyses have provided important perspectives on how we should explain and understand this government agenda as part of a process of neoliberal state crafting. This article offers a critical yet productive examination of these perspectives, arguing that their utility lies in how they can be employed, and therefore modified and adapted, in conjunction with studies of local practice which emphasise the messy realities of policy enactment and, with that, the possibility for contestation and challenge. Such an approach, based broadly on the tenets of critical realism, is founded on an alternative conception of state power, one that sees state power as having a more complex quality that is dependent on the agency of local actors.

Keywords: Troubled families, state intervention, critical realism, power.

\section{Introduction}

In August 2011, rioting took place in London and other urban areas across England. The political narrative that accompanied the riots imbued the events with a wider social significance and framed them as symptomatic of a 'moral collapse' within a 'broken society'. In his first public statement on the riots, the former British Prime Minister, David Cameron, argued that:

parts of Britain are sick, the one word I would use to sum that up is irresponsibility. The sight of those young people running down streets, smashing windows, taking property, looting, laughing as they go, the problem of that is a complete lack of responsibility, a lack of proper parenting, a lack of proper upbringing, a lack of proper ethics, a lack of proper morals. That is what we need to change. (Cameron, 2011b)

As the quote illustrates, 'parenting' was central to many accounts of the social collapse that the riots were said to signify, with statements frequently linking irresponsible parenting with the immorality of the young people involved (De Benedictus, 2012). Those caught up in the riots were identified as living 'without fathers' and also 'without discipline'; their parents defined as lacking (Cameron, 2011a). The political reaction to these events represented a defining moment in the recent history of state intervention in the lives of 
families with the subsequent launch of the $£ 448$ million Troubled Families Programme (TFP).

This article focuses attention on explaining and understanding state intervention into the lives of families deemed 'troublesome', with specific attention on the TFP. It will be argued that policy analysis in this area has presented a somewhat bleak diagnosis, in the sense that contemporary responses to families with multiple disadvantages have been explained as part of an on-going neoliberal government project which reproduces class inequalities. While instructive, this body of work can be critiqued for being somewhat deterministic in its tendency to overplay the success of political projects and for paying insufficient attention to the power of local actors. This said, the primary aim of the article is not to provide a critique of policy analyses of the TFP. What this article attempts to do is advocate a theory informed research agenda that brings together critical policy analysis with studies of local practice in order to offer a more nuanced analysis of state power. Influenced by critical realist work, such as that of Gordon Hughes and Adam Edwards within the field of criminology, central to this is an understanding of state power that takes greater account of political agency.

The article is dived into three core sections. It begins by using policy documents and speeches to provide an overview of the genesis of the TFP and to detail the official government rationale for intensifying state intervention in the lives of a particular cohort of families deemed troublesome. It is these narratives that have often formed the basis of critical perspectives. The article then focuses attention on critical policy analyses that have accompanied this particular initiative and its historical antecedents. In the final section, the article moves on to present an alternative way of thinking about state power, one that places more weight on the role of agency. In so doing, the article introduces some key theoretical and conceptual elements of a critical realist approach to provide a more nuanced explanation of the TFP. In so doing, the analysis offered in this article is intended to be theoretical and critical but also productive in its aim to inform future research agendas. Similar efforts have taken place within the fields of housing and social work, as well as criminology (Hughes, 2007; Matthews, 2009; Oliver, 2012; Bengtsson, 2015; Somerville and Bengtsson, 2002). The article is informed by my involvement in a number of research projects over the last ten years and a review of the literature (Parr, 2015a, 2015b; Parr, 2011, 2008; Flint et al., 2011; Nixon et al., 2007, 2006).

\section{Troubled families, feral parents and the broken society: the argument for state intervention}

Concerns about a lack of parental responsibility and family breakdown predates the 2011 riots and was particularly prominent during the previous decade manifest in the New Labour Government's policies to address anti-social behaviour (ASB) and social exclusion (Hancock and Mooney, 2012). In the 1990s, when New Labour's ASB policy programme first emerged, it was within a wider context characterised by anxieties around high crime rates, new forms of disorder, including 'white riots' in 'sink estates', and a climate defined by a fear of a generation of 'feral' children (Gilling, 2007; McLaughlin, 2002). A key source of disorder was presented as a minority of failing parents who did not know how, or were unwilling, to discharge their parental responsibilities, and who were therefore raising a generation of ill-behaved children. A key discourse that framed 
the New Labour narrative was Murray's theory of the underclass whereby 'excluded' populations are conceived of as morally deficient (Parr, 2012; Murray, 1990).

The influence of 'underclass' thinking has continued, perhaps even more explicitly, within the Coalition (2010-2015) and Conservative Party Governments' policies (2015-). The former Work and Pensions Secretary lain Duncan Smith regularly referred to a growing underclass characterised by 'chaos and dysfunctionality' within the wider context of 'Broken Britain'. The notion of a Broken Britain was driven by the work of Duncan Smith's Centre for Social Justice and its Social Justice Policy Group which aims 'to seek effective solutions to the poverty that blights parts of Britain'. ${ }^{1}$ The group's most prominent publication, Breakdown Britain (CSJ, 2006) identified five interrelated 'drivers' of poverty: economic dependence and worklessness, family breakdown ('dad-lessness' in particular), addiction, educational failure and indebtedness. Considerable attention was given to 'family breakdown', and, as Slater (2014) explains, the core principles of the 'underclass' thesis could be found within the definition of familial strife provided: 'We have adopted an inclusive use of the term "family breakdown" which can be summed up in three key words: dissolution, dysfunction, and "dad-lessness"' (CSJ, 2006: 29).

Prior to the Conservative party's election success in 2010, Cameron and Duncan Smith seized on a number of exceptional high profile crimes to evidence Britain's social and moral breakdown. The death of Baby Peter in North London in 2007, Karen Matthews' conviction for kidnapping her nine-year-old daughter in Dewsbury in 2008 and the conviction of the 'Edlington Brothers' in Edlington in Doncaster 2009 were all framed within an underclass discourse in which moral disintegration was linked to single motherhood (Warner, 2013; Hancock and Mooney, 2012):

The verdict last week on Karen Matthews and her vile accomplice is also a verdict on our broken society. The details are damning. A fragmented family held together by drink, drugs and deception. An estate where decency fights a losing battle against degradation and despair. A community whose pillars are crime, unemployment and addiction ... These children suffered at the very sharpest end of our broken society. (Cameron, 2008)

These narratives and assumptions formed the backdrop to the TFP which gathered pace after the 2011 riots, and which drew heavily on a social underclass discourse (Churchill, 2013). The blame for the riots was clearly placed upon the lone, workingclass mother and fatherless families, what De Bendictis (2012) has called a 'feral parent' discourse:

I don't doubt that many of the rioters out last week have no father at home. Perhaps they come from one of the neighbourhoods where it's standard for children to have a mum and not a dad ... where it's normal for young men to grow up without a male role model, looking to the streets for their father figures, filled up with rage and anger. So if we want to have any hope of mending our broken society, family and parenting is where we've got to start. (Cameron, 2011a)

Through a focus on the failings of families and parents, a narrative of blame and individual deficit and culpability attributed the problems of rioting, not to structural issues of poverty and inequality, but to behavioural causes: 'these riots were not about poverty' but rather 'about behaviour. People showing indifference to right and wrong. People with a twisted moral code. People with a complete absence of self-restraint' (Cameron, 
2011a). Indeed, Cameron has claimed that 'poverty of parenting' is of greater concern than material poverty: 'differences in child outcomes between a child born in poverty and a child born in wealth are no longer statistically significant when both have been raised by "confident and able" parents' (Cameron, 2010; Gillies, 2011). Parents were seen to be lacking on the basis that they had learned their own parenting skills from their own inadequate parents. This represents a 'cycle of deprivation' approach (Welshman, 2008), which explains the inter-generational transmission and inheritance of deprivation of disadvantage in terms of parental deficit, located in the alleged faulty behaviours of the individuals and their families, reproduced from one generation to the next:

In many cases their problems began with their own parents and their parents' parents, in cycles of childhood abuse, violence and care which are then replayed in their own lives. Family, and its influence past and present, was the pervading subject of conversations. (DCLG, 2012)

I want to talk about troubled families ... [they] are the source of a large proportion of problems in society. Drug addiction. Alcohol abuse. Crime. A culture of disruption and irresponsibility that cascades through generations. (Cameron, 2011c)

Linked to the inheritance of disadvantage, the welfare system - and in particular benefit dependency - was also identified as a source of malaise at the heart of the broken society (Arthur, 2015). Not only were families identified as a cost to government finances, but they were identified as a source of low aspiration inciting laziness (Crossley, 2015). Ironically therefore, although state intervention in welfare was cited as a primary cause of the 'irresponsibility' which ultimately produces troubled families (Hancock and Mooney, 2012), this in turn warranted intrusive state intervention into their lives:

The scheme is working because for the first time troubled families are being shown a bit of tough love. For too long the system allowed them to be cuddled into the system, giving the most vulnerable no obvious exit from the cycle of despair. This was not only damaging to one generation but to the future generations growing up in households without role models, rules or any idea of routine or structure. (Pickles, 2013)

We know that employability and - ultimately - employment is critical to tackling the often intergenerational cycle of benefit dependency and low aspiration for families with particularly complex needs. (DCLG, 2013)

This narrative that located the 'problem' with the family, and thereby linked the need to fix the 'broken society' with a requirement to fix the 'broken family', legitimated and gave impetus to the government's TFP. The aims of the TFP required the 152 upper tier local authorities in England to 'turn around' the lives of an estimated 120,000 families defined as having multiple problems by new or existing programmes over three years (April 2012 to May 2015). This brought with it a strengthening and deepening of state interventionist programmes in order to help families out 'of this cycle of despair and give their children a better chance in the future' (DCLG, 2014).

The primary target groups were highly specific - families with co-occurring problems of household welfare reliance; school exclusion, truancy and persistent school absence problems; and youth convictions or youth and/or adult anti-social behaviour problems (DCLG, 2012). A fourth category was introduced after the programme was launched 
to allow for discretion which enabled local authorities to include families they might be concerned about and who represent a 'high cost to the public purse'. The 120,000 families 'troubled families' were framed as a homogeneous group that all share the same perceived failings; a 'lack of resilience, insight and the capability to overcome problems' (Lloyd et al., 2011). The social and economic threats posed by the social underclass were emphasised. It was estimated that the 120,000 'troubled families' cost the state $£ 9$ billion, with the vast majority of that amount spent on reactive services, responding to the families' problems and the problems they caused for others (Hayden and Jenkins, 2014). The TFP was devised on a Payment by Results model, with local authorities paid an attachment fee for each 'troubled family' they worked with, and a further allocation of funding dependent on certain outcomes being met. In 2013, it was announced that the TFP would be extended to work with up to 400,000 more families, funded by $£ 200$ million from six government departments in 2015 to 2016. The scheme was also expanded in order to help children under five and families experiencing debt, drug and alcohol addiction, domestic violence and mental and physical health problems.

\section{Intervening in the lives of 'troubled' families: neoliberal statecraft}

State intervention into family life is not new, but the TFP represents a highly interventionist and targeted phase of family policy, bringing with it a shift in the boundaries between family and the state. Families with children caught in the youth justice system or at the extreme end of the continuum of risk have always been subject to state intervention, but the UK has historically been considered either not to have a family policy as such or, at the most, to have implicit family policies. Until quite recently, there was broad consensus in the UK that, outside of the school, children were the responsibility of their individual parents (in practice, mainly mothers) (Featherstone, 2006). With the advent of the New Labour government in 1997, family life and bringing up children was effectively re-positioned as a public rather than a private matter. There was an explicit concern with the family and parenting as a designated area of policy intervention. This shift was heavily influenced by efforts to address public concerns about crime and public order (Gillies, 2005a).

The family, once perceived as the bastion of private life into which the state had no right to intervene except to protect life and limb, now is the site of much government activity and intervention. Not only does the state see fit to try to regulate what people put on their dinner tables with endless (and often contradictory) advice and guidance, but it has taken a much more proactive role in parenting. (Crawford, 2006: 456)

This highly interventionist agenda continued under the Coalition and now the Conservative governments, both of which relate the wellbeing of society to family practices, such that the word 'parent' itself is now more commonly viewed as an adjective or verb: Mothers and fathers 'parent' children and childrearing is re-framed as a job requiring particular knowhow and expertise (Gillies, 2011).

Theorising this interventionist agenda, there is a field of what might be called critical policy perspectives that have emerged to analyse and critique family policy more broadly and specifically the TFP together with its predecessor family intervention projects which were initiated under New Labour and which sought to address the 
'anti-social' behaviour of the most 'challenging' families. Although different conceptual and theoretical frameworks have been used to help us understand and explain these policies, a core strand of this critical commentary more or less explicitly focuses on the effects of power, by placing the TFP within the context of the neoliberal state and capitalist class relations.

One such line of analysis has located family interventions, such as the TFP, as part of a broader project of welfare reform, which has its roots in a social investment rationale. Building on the underclass discourse which emphasises the cultural pathology of the poor, this rationale has a future-orientated perspective and services are provided to families... on the basis that the investment will pay off in the future, in terms of promoting labour market participation and individual employment opportunities, or, more negatively, in preventing disproportionate demands on service provision. This stands in contrast to a 'here and now' perspective, in which family and children's wellbeing are prioritised and parents (usually mothers) are seen as welfare subjects in their own right (Featherstone et al., 2012; Featherstone, 2006; Lister, 2006):

In this context, parents (more often poor women) were no longer seen as welfare subjects in their own right, worthy of support, but simply as conduits for ensuring the welfare of their children through the taking on of parental responsibility. (Featherstone et al., 2012: 622)

The TFP with its explicit emphasis on encouraging parents to become part of the 'hardworking' majority by finding paid employment can be interpreted as a social investment type of family project aimed at producing competent neoliberal subjects (Gillies, 2014).

This investment in families, it is claimed, brings with it a requirement for families to conform to the moral values of the mainstream and to normative definitions of successful and competent parenting. According to critics, this amounts to a top-down, authoritarian programme of 're-training' in which parents are encouraged to police themselves and self-discipline with the purpose of becoming conforming and productive such that any remaining 'troubles' are disregarded. From this perspective, the state acts as an 'enabler' rather than provider, with interventions aimed at encouraging parents to become sufficiently skilled in the 'job' of (neo-liberal) parenting (Smith, 2015; Gillies, 2005a, 2005b). The act of achieving this behaviour change is not through overt methods of control, but through negotiation and persuasion from key workers accepted by families as credible and encouraged to work 'creatively'. These welfare workers - who, wittingly or not, comply with an oppressive state (Dobson, 2015) - are thought to be integral to a new spirit of capitalism (Garrett, 2012), which ultimately helps to sustain the capitalist order in times of austerity.

In this process, family needs become equated with personal deficiencies in their attitudes and ways of thinking, a process underpinned by stigmatisation and negative labelling (Gray, 2009; Goldson and Jamieson, 2002). This overlooks how poor parenting more often than not is a result of poverty and a limited income, and the stress which accompanies these (La Placa and Corlyon, 2016). The TFP moves away from structural interventions - which might involve changing background conditions and material resources - towards those that are more behavioural (Daly and Bray, 2015), and, in so doing individualises the problems families have and the difficulties parents might encounter bringing up their children. It is argued that interventions framed at the level of 
the individual and family merely seek to change parenting processes in order to counter poor social and physical environments.

Crossley (2015) draws on both Bourdieu and Wacquant to explain the TFP as a neoliberal form of governing families:

The omnipresence of 'austerity' and the wide-ranging and punitive response to the riots, leading into the development of the TFP, can be understood as an exercise in 'state-crafting' where the 'welfare state' is rolled back at the same time that interventionist programmes aimed at managing and containing 'troubled families' are rolled out (Crossley, 2015).

Here, the TFP is conceived of as a state-led form of intrusive social control that is coercive and exclusionary. Crossley frames the programme as one that is designed and developed by the right hand of the state (what Bourdieu identifies as the fiscally minded, technocratic centre), with nationally set criteria and outcomes monitored from Whitehall, and funded by a Payment by Results model linked to the coalition government's 'long-term economic plan'. It is understood as ideological within the neoliberal project, diverting attention away from the impact of government austerity measures and welfare reforms. It therefore serves to maintain class inequalities and works to shore up the capitalist system in times of swingeing budget cuts. According to Crossley (2015), we should see the TFP as a punitive and muscular interventionist programme, and an integral part of aggressive neoliberal state-crafting. For Rodger, this also entails a blurring of the boundaries between social care and social control such that it produces criminalising agendas: chronic and deep-lying social problems often only become sites for state intervention if they are linked to crime and disorder issues (Rodger, 2008, 2012).

In the face of autonomous global economic processes, and largely uncontrollable macroeconomic problems which place governments in a subordinate relationship to global financial forces, governance of present day society is focused on the internal management of the behavioural predilections of populations, especially those living on the margins of economy and society. It is this aspect of contemporary governance that leads to the criminalization of social policy. (Rodger, 2012: 416)

Furthermore, according to Tyler, the underclass discourse that emerged after the riots of 2011 should be understood as part of a much larger effort to procure consent for the rolling out of neo-liberal economic and social policies that punish the most socially marginal and economically disadvantaged (Tyler, 2013: 7).

Although different in their emphasis and theoretical lineage, in many of the critical accounts of the TFP and family interventions more generally, the dynamics of class and capital accumulation figure as the main forces driving policy, and the TFP is located as an example of the subordination of social policy to economic policy. Likewise, the role of a powerful coercive, punitive and disciplinary state is central in the analyses of these critics. In this type of analysis, the state is essentially a capitalist state, and the agencies involved in the TFP form part of a new statecraft, which, while claiming to act in the public interest, are understood to act primarily to secure the interests of capital (Stenson, 2000). 


\section{An alternative vision of state power}

The sorts of theoretical debates detailed above have been subject to challenge on the basis of a flawed conception of (state) power that does not attach sufficient importance to political agency. While critical commentators' analyses are not always grounded in the abstract and so recognise variation in the materialisation of the TFP at a local level, they do tend to downplay the importance of agency and choice and, in turn, the complexity of practice. As such, critical policy analyses tend to offer an overly structural and somewhat deterministic analysis of family policies in which the capitalist state and the market are accorded explanatory privilege (Hughes, 2007). Furthermore, with an overemphasis on global and generalised processes together with a lack of attention on struggle, negotiation and compromise, it is also argued that the approach fails to account for or provide an adequate framework for explaining and understanding local variation. Hughes (2007) has referred to such work as a 'radical totalitarian' thesis and suggests that in failing to explore the policy making and implementation process, such work does not tell us about the tangible outcomes of actors' intentions, and their 'success' or 'failure' when put into practice, overplaying the success of political projects. Moreover, the particular normative stance, that of 'dystopianism', almost removes the possibility that projects falling under the TFP banner can have positive effects for people, and is therefore, by implication, theoretically and politically foreclosed in its analysis and critique. Indeed, it is less common to see critical commentators engage explicitly in political arguments that address what may be both alternative and practical ways of addressing the 'real' problems associated with multiple disadvantages.

In response, Edwards and Hughes (Edwards and Hughes, 2012, 2009; Hughes, 2007) place greater emphasis on the political agency of workers, and argue that the manner of local implementation is defined by 'messy instabilities' and unevenly developed practice. Giving voice to this, there is a growing body of empirical research that demonstrates how front-line workers do not straightforwardly implement regulatory social policy (Dobson, 2015; Prior and Barnes, 2011). Alternative perspectives on the TFP and its predecessors, family intervention projects, have been proffered (Davies, 2015; Hayden and Jenkins, 2015; Sen, 2016), some of which have focused specifically on the interplay between local and central forces. Researchers have, for instance, examined the importance of local policy interpretations in constructing meaningful practice within national problem figurations and policy frameworks; comparing the rhetoric and reality of intervention strategies, demonstrating evidence of local contestation and resistance (Ball et al., 2016., Bond-Taylor, 2015a; Parr and Nixon, 2009). Such work has revealed how many local authorities resist the language of the troubled families programme and avoid the term 'troubled families' in their local services (Hayden and Jenkins, 2014). It also draws attention to how the realisation of services is dependent on the professional identity and 'habitus' of front-line staff (Parr, 2015a; 2008). Flint (2012) has made the point that family intervention can have progressive as well as punitive dimensions and that this is, in part, associated with class, comportment and orientation of workers who are not always ciphers of middle class values. Parr (2015b) has also suggested that there has been a return to a 'key worker' model of support in which 'the relationship' and working in responsive, individualised ways is central. 'Good' relationships grounded in a personcentred practice is something long promoted by social workers, and there are examples of how 'the relationship' has had a beneficial impact on the emotional and psychological 
wellbeing of women. It would seem therefore that more traditional discourses of welfare and care have not been displaced absolutely for many of the social actors, professionals and practitioners working within the TFP (Bond-Taylor, 2015b).

Building on both structural policy analyses and empirical studies of practice, the theory-informed research agenda this article proposes is one that looks beyond a statecentred conception of the TFP. Underpinning this approach is what can be broadly referred to as critical realist work on the micro-dynamics of how political agency is negotiated beyond the central state's formal boundaries (Hughes, 2007; Edwards and Hughes, 2012, 2009; Goldson and Hughes, 2010). This perspective brings with it a different conception of power, and of state power in particular. Such an approach does not deny the power that state-agencies bring to bear on family projects, but recognises the inter-relational features of political power that underpin the implementation and operationalisation of TFP policy. In emphasising the local political agency of practitioners, this approach argues for the centrality of the notion of 'power-dependence' in understanding the relationships between the various (state and non-state) policy actors who have access to different types and levels of resources. For Hughes, this represents the central paradox of political power:

Actors who possess the potential to govern are not powerful when they are actually governing, but neither are they powerful when they seek to govern because they are dependent on others to carry out their commands. (2007: 188)

Here state power has a complex quality. Policy agendas, imperatives and discourses are understood to not be imposed top-down in an uncomplicated manner but interact with other dynamics via social relationships which include the contribution of those who are not so powerful. As Jupp (2013: 173) suggests:

Spaces of policy interventions can be seen as 'hybrid' spaces in which everyday life and emotions always 'exceed' either policy or theoretical frameworks, but that both remain relevant and indeed are powerful aspects of these spaces.

This approach can be situated within a broader body of work that has examined the policy implementation process. This work has drawn attention to the implementation gap' between policy and practice, and the way in which the central state is dependent on 'street level bureaucrats' or front-line practitioners who produce, modify and negate policy (Barrett, 2004; Lipsky, 1980). Although not a self-proclaimed realist, for Clarke (2004, 2007), this is about rescuing 'the social' -, defined by him as a field of shifting and contested relations and positions with a 'life of its own' - and thereby moving beyond statecentred approaches. The consequences of such policies, such as the TFP, cannot therefore be predicted or articulated within the straightforward narrative of understanding that seems to prevail within critical policy analyses (Simpson et al., 2015). This is particularly the case given the uneasy tension between localism and central control at the heart of the TFP, the effects of which are yet to be fully explored (Ball et al., 2016). Indeed, despite a certain amount of central control and regulation, the programme exists in many different guises across local authorities within England (Hayden and Jenkins, 2014).

Understanding this more complex notion of state power means recognising how human agency, reasoning and choice lead to and 'cause' certain (unintended) consequences. This means paying attention to intention and meaning, and placing 'the 
local' at the centre of the analysis in a way that recognises the multiple, complex and contingent factors that generate social phenomena. Despite an emphasis on agency, this approach is not an interpretivist analysis offering specific perspectives and a 'rich description' of 'lived experience' (Oliver, 2012). While some are theoretically advanced, empirical studies of practice can be criticised for offering a narrow understanding of human power and agency and for not always embedding analysis in wider social contexts that also have causal significance (Somerville and Bengtsson, 2002). Such approaches can sidestep questions of underlying social structures and thereby deny the primary importance of class, state or economic relations, instead concentrating, for instance, on networks of power-knowledge relations. In such analyses, it is not always clear what power is exercised for and also what any resistance may is exercised against (Joseph, 2004). These studies of practice can also offer uncomplicated 'positive' narratives of the 'good welfare worker who overcomes or resists pernicious policy and practice contexts' (Dobson, 2015). Related to this, there is not always a clear theoretical linkage from which to draw conclusions that have relevance beyond a particularistic case study.

Within a critical realist framework, studies of the TFP would maintain a dual focus on agency or individual action as well as social structure. Social structures refer to relatively enduring relationships between social positions and practices that constrain individuals' capacities and are the enabling conditions for human action (Matthews, 2009). These structures (such as those of the state, neoliberal practices and discourses) contain powers, mechanisms or, more simply, ways of acting which work to produce outcomes that generate events and experiences. People consciously and unconsciously interact with, and thereby reproduce or transform, the social structures that enable and constrain their actions. That said, agency and structure cannot be conflated or collapsed into one another; they are two separate phenomena with relative autonomy. Human action can therefore also change society and is potentially liberating and able to refashion social relations in the direction of greater humanity, freedom and justice (Matthews, 2009). Related to this is the recognition that the social world is an open system defined by complexity; it is multi-causal and multi-layered (Oliver, 2012). This means that the concrete outcomes associated with the TFP will be conditioned by the uniqueness of geographical and historical context, what Sayer (2000: 16) calls 'contingent necessity': 'In our complex social world, multiple causal mechanisms, including the interpretation of each situation made by each individual, constantly interact with, negate and reinforce each other' (Oliver, 2012: 374). As Matthews makes clear, state interventions are delivered by, and to, active subjects, and are open to interpretation and revision at every stage of the process, and can indeed fail at any one of a number of stages (Mathews, 2009).

Critical realist research therefore involves a kind of 'vertical' explanation whereby one mechanism or structure is shown to be the product of another. In this sense, theorising focuses not merely on the relationship between empirical observations. Rather, events and experiences (and actors' analyses of these events and their actions) are linked to a 'real' domain made up of structures and their underlying generative mechanisms. Frauley (2007) gives the example of relations of power which are 'not directly observable but can be inferred to exist from their effects in the social world' (2007: 620). Explanations of this sort represent a logical extension for methodologies that encourage researchers to ask 'what are the larger structural issues here and how do these events play into or effect what I am seeing?' (Corbin and Strauss, 2008, in Oliver, 2012: 10). This also involves separating out the necessary and contingent, helping us to understand what must be from 
what might be the case and in turn enabling us to identify mechanisms in one context that may be recognisable in other contexts (Bengtsson, 2015).

To illustrate, in a critical realist study of the genesis of an intensive support project for families accused of anti-social behaviour, Parr (2009) highlights the complex combination of political and cultural mechanisms that gave rise to the policy 'problem' and the subsequent response within one particular locality. A number of necessary causal factors are identified including: the construction of a 'convincing narrative'; the support of a coalition of actors to advance the problematisation; and the establishment of institutional practices. The project's ultimate terms of reference and internal structure, however, were contingently forged within the space of local power struggles aimed at making the project strategically necessary. In a bid to render the project politically viable, for instance, a discourse of 'need' was effectively colonised by one of behaviour control, and what might have been more straightforwardly a social policy was suffused with an agenda directed at addressing concerns about the containment of disorder, in part through the utilisation of enforcement-based technologies of control.

The TFP requires careful evaluation in order to identify the causal mechanisms in play as it is implemented. Therefore, in order to explain and understand the nature of state intervention in the lives of families deemed 'troublesome', questions need to be asked of the TFP about how wider economic and political developments and corresponding neoliberal ideas and practices manifest in TFP services; how TFP practitioners contribute to the exercise of class power; and what it is about the TFP that reinforce class inequalities and socio-economic disadvantage. In addition, research needs to explore how the impact of services and projects is rooted in the culture of specific organisations and local authorities; and how the interests of different groups and actors with access to different resources are brought to bear on practice? Adequate explanations will take the agency of actors' seriously as well as the social context within which they operate.

Theory is of primary importance in this endeavour. The role of theory (Sayer, 1992, 2000 ) is to generate hypotheses about the nature of social structures, while identifying their effects is an empirical question, essentially entailing a movement between the concrete and the abstract. Sayer (2000) suggests that although knowledge about relatively durable and pervasive social structures can be theorised independently of empirical research, social theory can rarely be applied to actual situations without supplementary empirical information.

The conceptual tools that critical policy analyses provide can be used to aid our understanding of the TFP. They are instructive in pointing towards general shifts in policy making at a national level for instance, and draw our attention to the distinctly punitive and stigmatising elements of family intervention policies that have an effect not only on practitioners and service users but also on wider society. Indeed, Levitas has claimed that the label 'troubled families' is part of a 'discursive strategy' which has been 'successful in feeding vindictive attitudes to the poor' (Levitas, 2012: 5) reflected in the media as a 'shameless culture' (Butler, 2014). Critical perspectives also work to centre analytical attention on questions of underlying social structures and the importance of the state and economic relations. Indeed, we should be in no doubt about the considerable power that lies with the central state in imposing obligations on the TFP. Moreover, it is important to recognise wide-ranging social and economic reforms are needed to address material disadvantage and deepening inequalities that local resistance, on the part of key workers within the TFP, is unlikely to be able to address (Ball et al., 2016). In 
isolation, however, these perspectives can frame the TFP as a unitary state-centred activity and tend to underplay its contested, complex and socially located nature. While critical policy analyses are not always characterised by an absence of empirical data, the latter are often analysed in order to identify how the state 'bears down on' families (Dobson, 2015). Even when grounded in the empirical, such an approach tends to channel the vision of the social researcher onto those practices that fit the problematisation and they do not provide an adequate framework for local variation (Edwards and Hughes, 2009). Sociological analysis of state intervention in the lives of families deemed 'troublesome' therefore needs to be adapted alongside empirical research that takes better account of the agency and choices of local actors, and the range of necessary and contingent determinants of the policy. The theoretical tools on which critical commentators draw, such as Crossley's use of Bourdieu, could enable such an actor-centred approach to the state (Arnholtz and Hammerslev, 2013).

It is important to also note that the critical realist project is closely tied to conceptions of emancipation and the possibility of social improvement. When we think about the TFP, we must also recognise the necessity to proffer possibilities for progressive interventions and propose alternative visions (Matthews, 2009). The challenge is for academics to consider what is a credible alternative vision for policy with families with complex needs and what is an appropriate kind of state intervention. Is it the case that no state interventionism is the option? Is there a feasible and or desirable alternative to the TFP? And, if so, how might this be realised? Is there are any opportunities that the TFP policy offers or is it necessarily about the regulation and control of the already socially excluded?

\section{Conclusion}

In the response to the 2011 riots, a stigmatising narrative drawing on an underclass discourse characterised the families of the young people involved as morally deficient, inadequate and irresponsible, rather than disadvantaged and excluded. Soon after, the TFP was launched by the Coalition government aimed at changing the generational patterns of poor parenting in the most 'troubled families', and thereby reducing the cost to the state.

Critical literature on the TFP and family support policies more broadly are concerned with (either implicitly or explicitly) how power and control are exercised, and with what purpose. Critical commentators have drawn attention to ideologies that inform the policy and posed questions regarding the rationale behind policy developments in this area and, with that, the goals of TFP activities. The analytical strengths of these approaches lie in the explanatory privilege accorded to the way in which the TFP may act as an instrument of capitalist economic interests. This article has argued however that the TFP has been conceived as a top-down strategy of control with a totalising view of power and an exaggerated focus on the punitive nature of the TFP. This has detracted from the development of a more progressive realist account of the TFP. The article claims that policy programmes are in fact defined by power-dependence and are open-ended, ambiguous and multi-faceted, underlining how 'the state' is not a homogenous entity. This recognition brings with it the need for new approaches to researching the TFP which move beyond policy analyses or critique on the one hand and studies of practice on the other. To this end, it draws on ideas derived from critical realist criminology to propose an analytical framework for the purpose of achieving a more nuanced analysis of the exercise of power. 
Such an analysis can combine a critique of punitive and stigmatising national policy narratives and agendas with a recognition of the agency of front-line workers to circumvent such trends. Critical realism provides a scheme for mapping out the complexity of policy enactment through a consideration of underlying multiple pressures and interests, and the different ordering of these relations. Critical realism offers a sophisticated analysis of power providing a way to explore the interplay between different social and political forces.

If we are to better explain state intervention into the lives of families deemed troublesome, further research is needed to develop, both theoretically and empirically, our understanding of state power and how the TFP policy comes into being. This article is intended to open up further debate, discussion and study.

\section{Note}

1 http://www.centreforsocialjustice.org.uk/about-us

\section{References}

Arnholtz, J. and Hammerslev, O. (2013) 'Transcended power of the state: the role of actors in Pierre Bourdieu's Sociology of the State', Distinktion: Journal of Social Theory, 14, 1, 42-64.

Arthur, R. (2015) 'Troubling times for young people and families with troubles - responding to truancy, rioting and families struggling with adversity', Social and Legal Studies, 24, 3, 443-64.

Ball, E., Batty, E. and Flint, J. (2016) 'Intensive family intervention and the problem figuration of "troubled families"', Social Policy and Society, 15, 263-74.

Barrett, S. M. (2004) 'Implementation studies: time for a revival? Personal reflections on 20 years of implementation studies', Public Administration, 82, 2, 249-62.

Bengtsson, B. (2015) 'Between structure and Thatcher: towards a research agenda for theory-informed actor-related analysis of housing politics', Housing Studies, 30, 5 677-93.

Bond-Taylor, S. (2015a) 'Dimensions of family empowerment in work with so called "troubled" families', Social Policy and Society, 14, 3, 371-84.

Bond-Taylor, S. (2015b) 'Tracing an ethic of care in the policy and practice of the Troubled Families Programme: getting with the programme', Workshop 1: History \& Contemporary Practice, 11 February 2015, Durham University.

Butler, I. (2014) 'New families, new governance and old habits', Journal of Social Welfare and Family Law, $36,4,415-25$.

Cameron, D. (2011a) 'Speech on the fightback after the riots', 15 August, http://www.number10.gov.uk/ news/pms-speech-on-the-fightback-after-the-riots/ [accessed July 2016].

Cameron, D. (2011b) 'Statement on violence in England', 10 August, https://www.gov.uk/government/ speeches/pm-statement-on-violence-in-england [accessed July 2016].

Cameron, D. (2011c) 'Speech on plans to improve services for troubled families', 15 December, https://www.gov.uk/government/news/tackling-troubled-families-new-plans-unveiled [accessed July 2016].

Cameron, D. (2010) 'Supporting parents', speech to Demos, 11 January, http://www.demos.co.uk/files/ cameronspeechjan2010.pdf [accessed July 2016].

Cameron, D. (2008) 'There are five million people in Britain on benefits: how do we stop them turning into Karen Matthews', Daily Mail, 8 December.

Centre for Social Justice (2006) Breakdown Britain: Interim Report on the State of the Nation, London: Centre for Social Justice.

Churchill, H. (2013). 'Retrenchment and restructuring: family support and children's services reform under the coalition', Journal of Children's Services, 8, 3, 209-22. 
Clarke, J. (2004) 'Subjects of doubt: in search of the unsettled and unfinished', Paper prepared for CASCA Conference, London, Ontario, 5-9 May.

Clarke, J. (2007) 'Introduction: governing the social?', Cultural Studies, 21, 6, 837-46.

Crawford, A. (2006) 'Networked governance and the post-regulatory State? Steering, rowing and anchoring the provision of policing and security', Theoretical Criminology, 10, 4, 449-79.

Crossley, S. (2015) '"Realising the (troubled) family", "crafting the neoliberal state"', Families, Relationships and Societies, 5, 2, 263-79.

Daly, M. and Bray, R. (2015) 'Parenting support in England: the bedding down of a new policy', Social Policy and Society, 14, 4, 633-44.

Davies, K. (2015) Social Work with Troubled Families, London: Jessica Kingsley Publishers.

De Benedictis, S. (2012) '"Feral" parents: austerity parenting under neoliberalism', Studies in the Maternal, 4, 2, www.mamsie.bbk.ac.uk/documents/DeBenedictis_SiM_4\%282\%292012.pdf [accessed August 2016].

Department for Communities and Local Government (DCLG) (2014) Understanding Troubled Families, London: Department for Communities and Local Government.

Department for Communities and Local Government (DCLG) (2013) Delivery Agreement: Putting Troubled Families on the Path to Work, London: Department for Communities and Local Government.

Department for Communities and Local Government (DCLG) (2012) Listening to Troubled Families, London: Department for Communities and Local Government.

Dobson, R. (2015) 'Power, agency, relationality and welfare practice', Journal of Social Policy, 44, 4, 687-705.

Edwards, A. M. and Hughes, G. (2012) 'Public safety regimes: negotiated orders and political analysis in criminology', Criminology and Criminal Justice, 12, 4, 433-58.

Edwards, A. and Hughes, G. (2009) 'The preventive turn and the promotion of safer communities in England and Wales: political inventiveness and governmental instabilities', in A Crawford (ed.), Crime Prevention Policies in Comparative Perspectives, Cullompton: Willan Publishing, 62-85.

Featherstone, B. (2006) 'Rethinking family support in the current policy context', British Journal of Social Work, 36, 1, 5-19.

Featherstone, B., Broadhurst, K. and Holt, K. (2012) 'Thinking systemically-thinking politically: building strong partnerships with children and families in the context of rising inequality', British Journal of Social Work, 42, 4, 618-33.

Flint, J. (2012) 'The inspection house and neglected dynamics of governance: the case of domestic visits in family intervention projects', Housing Studies, 27, 6, 822-38.

Flint, J., Batty, E., Parr, S., Platts-Fowler, D., Nixon, J. and Sanderson, D. (2011) Evaluation of Intensive Intervention Projects, London: Department for Education.

Frauley, J. (2007) 'Towards an archaeological-realist Foucauldian analytics of government', British Journal of Criminology, 47, 4, 617-33.

Garrett, P. M. (2012) 'Re-enchanting social work? The emerging 'spirit' of social work in an age of economic crisis', British Journal of Social Work, 44, 3, 503-21.

Gillies, V. (2014) 'Troubling families: parenting and the politics of early intervention', in S. Wagg and J. Pilcher (eds.), Thatcher's Grandchildren, London: Palgrave Macmillan.

Gillies, V. (2011) 'From function to competence: engaging with the new politics of family', Sociological Research Online, 16, 4, 11.

Gillies, V. (2005a) 'Meeting parents' needs? Discourses of "support" and "inclusion" in family policy', Critical Social Policy, 25, 1, 70-90.

Gillies, V. (2005b) 'Raising the meritocracy: parenting and the individualisation of social class', Sociology, $39,5,835-53$.

Gilling, D. (2007) Crime Reduction and Community Safety: Labour and the Politics of Local Crime Control, Cullompton: Willan Publishing.

Goldson, B. and Hughes, G. (2010) 'Sociological criminology and youth justice: comparative policy analysis and academic intervention', Criminology and Criminal Justice, 10, 2, 211-30. 
Goldson, B. and Jamieson, J. (2002) 'Youth crime, the parenting deficit and state intervention: a contextual critique', Youth Justice, 2, 2, 82-99.

Gray, P. (2009) 'The political economy of risk and the new youth governance', Punishment and Society, $11,4,443-58$.

Hancock, L. and Mooney, G. (2012) "Welfare ghettos" and the "broken society": territorial stigmatization in the contemporary UK', Housing, Theory and Society, 30, 1, 46-64.

Hayden, C. and Jenkins, S. (2015) 'Troubled or troublesome: children taken into care and custody', in K. Davies (ed.), Social Work with Troubled Families, London: Jessica Kingsley Publishers.

Hayden, C. and Jenkins, J. (2014) 'Troubled families' programme in England: "wicked problems" and policy-based evidence', Policy Studies, 35, 6, 631-49.

Hughes, G. (2007) The Politics of Crime and Community, London: Palgrave Macmillan.

Joseph, J. (2004) 'Foucault and Reality', Capital and Class, 28, 1, 143-65.

Jupp, E. (2013) 'Enacting parenting policy? The hybrid spaces of Sure Start Children's Centres', Children's Geographies, 11, 2, 173-87.

La Placa, V. and Corlyon, J. (2016) 'Unpacking the relationship between parenting and poverty: theory, evidence and policy', Social Policy and Society, 15, 1, 11-28.

Levitas, R. (2012) 'There may be trouble ahead: what we know about those 120,000 "troubled families"', Poverty and Social Exclusion in the UK, Policy Response Series No. 3, Swindon: ESRC.

Lipsky, M. (1980) Street-Level Bureaucracy - Dilemmas of the Individual in Public Services, New York: Russell Sage Foundation.

Lister, R. (2006) 'Children (but not women) first: New Labour, child welfare and gender', Critical Social Policy, 26, 2, 315-35.

Lloyd, C., Wollny, C. and Gowland, S. (2011) Monitoring and Evaluation of Family Intervention Services and Projects between February 2007 and March 2011, London: Department of Education.

Matthews, R. (2009) 'Beyond "so what?"' criminology', Theoretical Criminology, 13, 3, 341-62.

McLaughlin, E. (2002) 'The crisis of the social and the political materialisation of community safety', in G. Hughes, E. McLaughlin and J. Muncie (eds.), Crime Prevention and Community Safety: New Directions, London: Sage, 77-100.

Murray, C. (1990) The Emerging Underclass, London: Institute of Economic Affairs.

Nixon, J., Parr, S., Hunter, C., Sanderson, D. and Whittle, S. (2007) The Longer-Term Outcomes Associated with Families Who Have Worked with Intensive Family Support Projects, London: ODPM.

Nixon, J., Hunter, C., Parr, S., Myers, S., Whittle, S. and Sanderson, D. (2006) Anti-Social Behaviour Intensive Family Support Projects: An Evaluation of Six Pioneering Projects, London: ODPM.

Oliver, C. (2012) 'Critical realist grounded theory: a new approach for social work research', British Journal of Social Work, 42, 2, 371-87.

Parr, S. (2015a) 'The troubled families workforce and occupational identity: a critical introduction', in K. Davies (ed.), Social Work with Troubled Families, London: Jessica Kingsley Publishers.

Parr, S. (2015b) 'Conceptualising "the relationship" in intensive key worker support as a therapeutic medium', Social Work Practice, 30, 1, 25-42.

Parr, S. (2012) 'Intensive family casework with "problem families": past and present', Family Science, 2, 4, 240-9.

Parr, S. (2008) 'Family intervention projects: a site of social work practice', British Journal of Social Work, $39,7,111-22$.

Parr, S. (2009) 'Confronting the reality of anti-social behaviour', Theoretical Criminology, 13, 3, 363-81.

Parr, S. and Nixon, J. (2009) 'Family intervention projects: sites of subversion and resilience', in M. Barnes and D. Prior (eds.), Subversive Citizens Power, Agency and Resistance in Public Services, Bristol: Policy Press.

Pickles, E. (2013) 'Our troubled families programme is turning round thousands of lives', 10 September, http://www.conservativehome.com/platform/2013/09/eric-pickles-mp-our-troubled-familiesprogramme-is-turning-round-thousands-of-lives.html [accessed July 2016]. 
Prior, D. and Barnes, M. (2011) 'Subverting social policy on the front line: agencies of resistance in the delivery of services', Social Policy and Administration, 45, 3, 264-79.

Rodger, J. (2012) 'Regulating the poor: observations on the "structural coupling" of welfare, criminal justice and the voluntary sector in a "Big Society"', Social Policy and Administration, 46, 4, 413-31.

Rodger, J. (2008) Criminalising Social Policy: Anti-social Behaviour and Welfare in a De-civilised Society, Cullompton: Willan Publishing.

Sayer, A. (1992) Method in Social Science: A Realist Approach, London: Routledge.

Sayer, A. (2000) Realism and Social Science, London: Sage.

Sen, R. (2016) 'Building relationships in a cold climate: a case study of family engagement within an "edge of care" family support service', Social Policy and Society, 15, 2, 289-302.

Simpson, D., Lumsden, E. and McDowall Clark, R. (2015) 'Neoliberalism, global poverty policy and early childhood education and care: a critique of local uptake in England', Early Years, 35, 1, 96-109.

Slater, T. (2014) 'The myth of "Broken Britain": welfare reform and the production of ignorance', Antipode, $46,4,948-69$.

Smith, R. (2015) 'Troubled, troubling or troublesome? Troubled families and the changing shape of youth justice', in M. Wasik and S. Santatzoglou (eds.), The Management of Change in Criminal Justice Who Knows Best? London: Palgrave Macmillian, 49-63.

Somerville, P. and Bengtsson, B. (2002) 'Constructionism, realism and housing theory', Housing, Theory and Society, 19, 3-4, 121-36.

Stenson, K. (2000) 'Crime control, social policy and liberalism', in G. Lewis, G. Gewirtz and J. Clarke (eds.), Rethinking Social Policy, London: The Open University/Sage, 229-44.

Tyler, I. (2013) 'The riots of the underclass? Stigmatisation, mediation and the government of poverty and disadvantage in neoliberal Britain', Sociological Research Online, 18, 4, 6.

Warner, J. (2013) 'Social work, class politics and risk in the moral panic over Baby P', Health, Risk and Society, 15, 3, 217-33.

Welshman, J. (2008) 'The cycle of deprivation: myths and misconceptions', Children and Society, 22, 2, 75-85. 